Dominik Damian Mielewczyk

Uniwersytet Gdański

dominikmielewczykprawo@wp.pl

ORCID: https://orcid.org/0000-0001-8887-2249

\title{
Należyta staranność adwokata \\ i radcy prawnego wykonujących zawód w ramach indywidualnej praktyki prawniczej (analiza porównawcza polskiego i amerykańskiego systemu prawnego)
}

http://dx.doi.org/10.12775/SIT.2020.029

\section{Wstęp}

Ze względu na doniosłość i znaczenie zawodów prawniczych w życiu społecznym zarówno profesja adwokata, jak i radcy prawnego, obok sędziego, prokuratora i notariusza, stanowią tzw. zawód zaufania publicznego. Ten szczególny, wyróżniony w systemie prawnym charakter wynika $z$ samej istoty oraz celu istnienia tych zawodów w społeczeństwie. Jak orzekł Trybunał Konstytucyjny, na gruncie obowiązującego ustawodawstwa każdemu ze wskazanych zawodów prawniczych przypisuje się różne tzw. czynności zawodowe oraz określone zadania, które „związane są $z$ ingerencją - w pewnym zakresie - w prawa i obowiązki innych podmiotów i dotykają różnych 
sfer życia osobistego i zawodowego" ${ }^{1}$. Konstytucja RP nie zawiera definicji legalnej pojęcia zawodu zaufania publicznego. Zostało ono jedynie nadmienione w art. 17, który stanowi normatywną podstawę prawną do tworzenia samorządów zawodowych w drodze ustawy. Trybunał Konstytucyjny ${ }^{2}$ w wyroku z 2002 r. powołał się na stanowisko Pawła Sarneckiego ${ }^{3}$, wskazując, że zawód adwokata (przy czym nie ulega wątpliwości, że wywód dotyczy także zawodu radcy prawnego) należy do zawodu zaufania publicznego, dlatego też ustawodawca uzależnia prawo jego wykonywania od spełnienia przez zainteresowanego określonych wymogów dotyczących kwalifikacji zawodowych i etycznych.

Wynika z tego, że jest to zawód polegający na obsłudze „osobistych potrzeb ludzkich, wiążący się z przyjmowaniem informacji dotyczących życia osobistego i zorganizowany w sposób uzasadniający przekonanie społeczne o właściwym dla interesów jednostki wykorzystywaniu tych informacji przez świadczących usługi”. Wykonywanie zawodu adwokata i radcy prawnego kształtowane jest także przez normy etyki zawodowej, tj. kolejno obwieszczenia Prezydium Naczelnej Rady Adwokackiej z 27.02.18 r. w sprawie ogłoszenia jednolitego tekstu Zbioru Zasad Etyki Adwokackiej i Godności Zawodu (Kodeks Etyki Adwokackiej) ${ }^{4}$ oraz załącznika do uchwały nr 3/2014 Nadzwyczajnego Krajowego Zjazdu Radców Prawnych z 22.11.14 r. w sprawie Kodeksu Etyki Radcy Praw-

${ }^{1}$ Zob. wyrok TK z 26 listopada 2003 r., SK 22/02, Dz.U. z 2003 r. Nr 206, poz. 2012.

${ }^{2}$ Zob. wyrok TK z 7 maja 2002 r., SK 20/00, Dz.U. z 2002 r. Nr 66, poz. 611.

${ }^{3}$ P. Sarnecki, Pojęcie zawodu zaufania publicznego (art. 17 ust. 1 Konstytucji) na przykładzie adwokatury, w: Konstytucja - wybory - parlament. Studia ofiarowane Zdzisławowi Jaroszowi, red. L. Garlicki, Warszawa 2000, s. 155 i n.

${ }^{4}$ Prezydium Naczelnej Rady Adwokackiej na podstawie uchwały nr 52/2011 NRA z 19 listopada 2011 r. ogłosiło jednolity tekst Zbioru Zasad Etyki Adwokackiej i Godności Zawodu (Kodeksu Etyki Adwokackiej) uchwalony przez Naczelną Radę Adwokacką 10 października 1998 r. (uchwała nr 2/XVIII/98) ze zmianami wprowadzonymi uchwałą Naczelnej Rady Adwokackiej nr 32/2005 z 19 listopada 2005 r., uchwałami Naczelnej Rad Adwokackiej nr 33/2011 54/2011 z dnia 19 listopada 2011 r. oraz uchwałą 64/2016 Naczelnej Rady Adwokackiej z dnia 25 czerwca 2016 r. 
nego ${ }^{5}$. Istotną rolę odgrywa również szczególna treść ślubowań dla adwokatów ${ }^{6}$ i radców prawnych ${ }^{7}$, tradycje korporacji zawodowych, funkcja, jaką pełnią te zawody w społeczeństwie, oraz szczególny charakter wykształcenia wyższego i uzyskania specjalizacji poprzez aplikację.

Nazwy zawodów adwokata i radcy prawnego podlegają ochronie prawnej i wiążą się $z$ ingerencją w prawa i obowiązki innych uczestników obrotu poprzez przyjmowanie od nich informacji i dotrzymania w tym względzie tajemnicy. Zdaniem Bogusława Banaszaka adwokat i radca prawny w pierwszej kolejności wykonują swoją pracę dla zaspokojenia interesu społecznego, nie zaś dla zysku ${ }^{8}$. Zawód prawnika to przede wszystkim pełnienie misji społecznej i działanie w imieniu szeroko rozumianego dobra ogółu poprzez profesjonalne świadczenie usług prawnych. Od adwokatów i radców prawnych oczekuje się wysokiego przygotowania do wykonywania zawodu, a zatem nieustannego podnoszenia kwalifikacji, umiejętności i uaktualniania wiedzy. W związku $\mathrm{z}$ tym pieczę nam prawidłowym wykonywaniem czynności związanych $z$ tymi dwoma zawodami ustawodawca przyznał samorządom zawodowym ${ }^{9}$.

${ }^{5}$ Na podstawie art. 57 pkt 7 ustawy z dnia 6 lipca 1982 r. o radcach prawnych (Dz.U. z 2014 r. poz. 637 i 993).

${ }^{6}$ Art. 5 ustawy z dnia 26 maja 1982 r. Prawo o Adwokaturze (tekst jednolity: Dz.U. z 2019 r. poz. 1513): „Ślubuję uroczyście w swej pracy adwokata przyczyniać się ze wszystkich sił do ochrony praw i wolności obywatelskich oraz umacniania porządku prawnego Rzeczypospolitej Polskiej, obowiązki swe wypełniać gorliwie, sumiennie i zgodnie z przepisami prawa, zachować tajemnicę zawodową, a w postępowaniu swoim kierować się zasadami godności, uczciwości, słuszności i sprawiedliwości społecznej”.

${ }^{7}$ Art. 27 ustawy o radcach prawnych (tekst jednolity: Dz.U. z 2020 r. poz. 75): „Ślubuję uroczyście w wykonywaniu zawodu radcy prawnego przyczyniać się do ochrony i umacniania porządku prawnego Rzeczypospolitej Polskiej, obowiązki zawodowe wypełniać sumiennie i zgodnie z przepisami prawa, zachować tajemnicę zawodową, postępować godnie i uczciwie, kierując się zasadami etyki radcy prawnego i sprawiedliwości”.

${ }^{8}$ B. Banaszak, Konstytucja Rzeczpospolitej Polskiej. Komentarz, wyd. 2, Warszawa 2012, s. 117.

${ }^{9}$ Zob. wyrok TK z 18 lutego 2004 r., P 21/02, Dz.U. z 2004 r. Nr 34, poz. 303. 


\section{Płaszczyzny odpowiedzialności adwokata i radcy prawnego}

Profesjonalni pełnomocnicy podlegają przepisom prawnym kreującym różne podstawy odpowiedzialności, które składają się na szeroko rozumianą odpowiedzialność o charakterze interdyscyplinarnym. Na gruncie omawianej materii możemy wyróżnić reżim odpowiedzialności: cywilnej, dyscyplinarnej (zawodowej) oraz karnej. Ramy niniejszego opracowania nie pozwalają na szersze omówienie kwestii odpowiedzialności dyscyplinarnej i karnej. Odpowiedzialność o charakterze dyscyplinarnym jest niezależna od odpowiedzialności cywilnej i stoi niejako obok niej, gdyż opiera się na wymogach i standardach wynikających z norm zawodowych. Odpowiedzialność cywilna i dyscyplinarna mogą się jednak krzyżować, na co zwróciła uwagę Hanna Czerwińska. Hipotetycznie bowiem może dojść do zbiegu podstaw tych dwóch odrębnych reżimów odpowiedzialno$\operatorname{ści}^{10}$. Warto jedynie wspomnieć, że działalność adwokatów i radców prawnych może wyczerpywać znamiona czynu zabronionego ${ }^{11}$, a co za tym idzie w myśl art. $11 \mathrm{zd}$. 1 Kodeksu postępowania cywilnego (dalej: k.p.c.) ${ }^{12}$ ustalenia wydane w prawomocnym wyroku skazującym co do popełnienia przestępstwa w postępowaniu przed sądem karnym wiążą sąd w postępowaniu cywilnym.

${ }^{10}$ H. Czerwińska, Odpowiedzialność cywilna adwokata na tle ubezpieczenia OC - uwagi $w$ świetle wybranych orzeczeń sadowych, „Wiadomości Ubezpieczeniowe" 2014, nr 1, s. 46.

11 M. Gutowski, Wpływ odpowiedzialności karnej zastępcy procesowego na odpowiedzialność cywilnoprawna, w: M. Gutowski, Umowa o zastępstwo procesowe, Warszawa 2009 s. 226-229.

12 Ustawa z 17 listopada 1964 r. Kodeks postępowania cywilnego (tekst jednolity: Dz.U. z 2019 r. poz. 1460). 


\section{Odpowiedzialność cywilna a stosunek zastępstwa procesowego}

W doktrynie prawniczej wyróżnia się trzy podstawowe rodzaje odpowiedzialności odszkodowawczej, tj. deliktową, kontraktową oraz gwarancyjno-repartycyjną. Dlatego też z perspektywy stosunku zastępstwa procesowego największe znaczenie będzie mieć odpowiedzialność ex contractu, na której to zostanie skupiona uwaga $\mathrm{w}$ dalszej części rozważań. Jedynie w ramach przypomnienia oraz wskazania na wielość potencjalnych przypadków odpowiedzialności należy przypomnieć, że normy wywodzone z treści art. 443 Kodeksu cywilnego (dalej: k.c.) ${ }^{13}$ wskazują na możliwy zbieg podstawy odpowiedzialności kontraktowej oraz deliktowej.

Zastępstwo procesowe należy do kategorii umów o świadczenie usług, a więc co do starannego działania, do których stosuje się odpowiednio, na podstawie odesłania zawartego w art. 750 k.c., przepisy o zleceniu w zakresie nieuregulowanym przepisami dotyczącymi funkcjonowania adwokatów lub radców prawnych ${ }^{14}$. Ustawodawca nie zdecydował się na wprowadzenie szczególnej regulacji względem kwalifikowanych pełnomocników w zakresie odpowiedzialności odszkodowawczej. Dlatego też w przypadku nienależytego wykonania zobowiązania, wynikającego $z$ zawartej $z$ mocodawcą umowy, która obejmuje świadczenie pomocy prawnej, polegającej na reprezentacji w postępowaniu sądowym, zastosowanie mają ogólne zasady odpowiedzialności odszkodowawczej za niewykonanie zobowiązań umownych. W związku z powyższym właściwymi są art. 471 i nast. k.c., a także art. 472 w zw. $z$ art. 355 § 2 k.c. Przywołane przepisy nakładają na adwokatów i radców prawnych obowiązek zachowywania należytej staranności uwzględniającej zawodowy charakter prowadzonej działalności ${ }^{15}$.

${ }^{13}$ Ustawa z 23 kwietnia 1964 r. Kodeks cywilny (tekst jednolity: Dz.U. z 2019 r. poz. 1145).

${ }^{14}$ Zob. wyrok SN z 19 grudnia 2012 r., II CSK 219/12, Lex nr 1294221.

15 Zob. wyrok SN z 08 marca 2012 r., V CSK 104/11, Lex nr 1215159. 
Przypisanie przez sąd naruszenia określonego obowiązku bez uprzedniego wyjaśnienia, czy w okolicznościach sprawy rzeczywiście ciążył na dłużniku taki obowiązek i czy ewentualne uchybienia w tym zakresie mogły w normalnym porządku rzeczy przyczynić się do powstania szkody, stanowi rażące naruszenie art. 471 i $472^{16}$.

Na podstawie art. 471 k.c. obowiązek naprawienia szkody za niewykonanie lub nienależyte wykonanie zobowiązania będzie spoczywać na profesjonalnym pełnomocniku (dłużniku), chyba że niewykonanie lub nienależyte wykonanie jest następstwem okoliczności, za które dłużnik odpowiedzialności nie ponosi. Przy czym ciężar dowodu niewykonania lub nienależytego wykonania zobowiązania spoczywać będzie na kliencie (wierzycielu) w myśl art. 6 k.c. ${ }^{17}$, a ciężar wykazania braku winy - na pełnomocniku $z$ uwagi na domniemanie winy. Aby móc mówić o odpowiedzialności odszkodowawczej, oprócz przesłanki zdarzenia będącego niewykonaniem lub nienależytym wykonaniem zobowiązania musi pojawić się także szkoda, a więc uszczerbek doznany przez poszkodowanego, oraz adekwatny związek przyczynowy, łączący ze sobą dwie pierwsze przesłanki. Jako zasadne należy ocenić stanowisko Macieja Gutowskiego, zgodnie z którym konstrukcja kontraktowej odpowiedzialności jest najważniejszym rodzajem odpowiedzialności po stronie zastępcy procesowego, a zarazem najbardziej złożonym i skomplikowanym w swej treści świadczeniem w ramach stosunku zobowiązaniowego, jakim jest obowiązek prowadzenia sprawy z należytą starannością ${ }^{18}$. Polski ustawodawca nie ograniczył stosowania przepisów o odpowiedzialności za niewykonanie i nienależyte wykonanie zobowiązania jedynie do zobowiązań, których źródłem powstania są umowy ${ }^{19}$. Dlatego też na podstawie art. 471 ustawodawca ustanawia reżim odpowiedzialności za naruszenie stosunku

16 Zob. postanowienie SN z 22 stycznia 2010 r., V CNP 52/09, niepubl.

17 Zob. wyrok SA w Białymstoku z 31 października 2017 r., I ACa 349/17, Lex nr 2453710.

${ }_{18}$ M. Gutowski, Umowa o zastępstwo procesowe, Warszawa 2009, s. 181$-183$.

19 T. Dybowski, w: System prawa prywatnego, tom III, red. E. Gniewek, Warszawa 2013, s. 184. 
zobowiązaniowego; treść tego przepisu jest szersza niż tylko to, co wyrażono w umowie. Dla zaistnienia roszczenia odszkodowawczego nie ma znaczenia zdarzenie kreujące zobowiązanie, którego nie wykonał lub nienależycie wykonał profesjonalny pełnomocnik ${ }^{20}$.

\section{Odpowiedzialność za brak należytej staranności}

Nie sposób stworzyć generalny model odpowiedzialności w stosunku zobowiązaniowym zastępstwa procesowego. Pojęcie to jest zbyt ogólne, a „jego ocena może następować jedynie przy uwzględnieniu indywidualnych cech łączącego strony stosunku zobowiązaniowego. Kwestię wadliwego wykonania zobowiązania można rozpatrywać jako rozbieżność pomiędzy faktycznie zaistniałym stanem rzeczy a treścią zobowiązania w kontekście takich elementów jak zachowanie terminu, miejsca, sposobu czy też jakości - rozumianych w szerokim znaczeniu" ${ }^{21}$.

$Z$ reguły na gruncie prawa cywilnego dłużnik ponosi odpowiedzialność za każdą postać i stopień winy, zarówno winę umyślną, jak i nieumyślną. Przypisanie dłużnikowi winy nieumyślnej jest z kolei możliwe tylko wtedy, gdy dłużnik nie zachował należytej staranności, chociaż powinien i mógł ją zachować, co określa się w prawie cywilnym mianem niedbalstwa (culpa). Wina nieumyślna jest oceniana niezależnie od cech osobistych dłużnika; służą do tego obiektywne mierniki staranności, stanowiące wzorce prawidłowego postępowania. Warto również przytoczyć pogląd, według którego uznaje się, że osoba pozostająca w stosunku kontraktowym ma większy obowiązek pilności niż inne podmioty, dlatego - mimo iż treść art. 472 k.c. wprost na to nie wskazuje - dłużnik odpowiada za szkodę wyrządzoną nie tylko $z$ winy nieumyślnej, lecz także,

${ }^{20}$ Zob. wyrok SN z 11 grudnia 1998 r., II CKN 86/98, Lex nr 50650.

${ }^{21}$ M. Gutowski, op.cit., s. 192-193. Por. T. Wiśniewski, w: Komentarz do Kodeksu cywilnego, Księga trzecia. Zobowiązania, tom III, red. J. Gudowski, Warszawa 2013, s. 518. 
zgodnie $z$ wnioskowaniem a minori ad maius, $z$ winy umyślnej ${ }^{22}$. Przypadki możliwości przypisania adwokatowi i radcy prawnemu winy umyślnej są rzadkie i nie budzą większych wątpliwości. Zobowiązany odpowiada za zawinione niewykonanie lub nienależyte wykonanie zobowiązania niezależnie od tego, czy nastąpiło ono w sposób umyślny czy też nieumyślny. O wiele trudniej jest ocenić kwestię niedochowania należytej staranności właśnie przy winie nieumyślnej.

W tym miejscu należy podkreślić, że zakres omawianej odpowiedzialności odszkodowawczej zarówno adwokata, jak i radcy prawnego będzie różnić się a casu ad casum. Granicami dopuszczalności kształtowania treści stosunku prawnego są wyłącznie: zakres ogólnej swobody umów dla kontrahentów, wymogi ważności czynności prawnej oraz unormowania prawa konsumenckiego (szczególnie art. 385 (3) w zw. z art. 385 (1) k.c.). Przy czym ograniczeniami wyłączenia odpowiedzialności w stosunku zastępstwa procesowego są natura tego stosunku, przymiot profesjonalisty po stronie pełnomocnika, a także możliwy status konsumenta po stronie klienta ${ }^{23}$. Artykuł 354 k.c. reguluje w sposób ogólny wykonanie zobowiązania po stronie zarówno dłużnika, jak i wierzyciela. Dłużnik powinien wykonać zobowiązanie zgodnie $z$ jego treścią i w sposób odpowiadający jego celowi społeczno-gospodarczemu oraz zasadom współżycia społecznego, a jeżeli istnieją w tym zakresie ustalone zwyczaje - także w sposób im odpowiadający. Wierzyciel powinien wywiązywać się z ciążących na nim obowiązków w taki sam sposób.

Niezachowanie należytej staranności związane jest ściśle $z$ winą nieumyślną, którą można przypisać profesjonalnemu pełnomocnikowi w sytuacji, gdy nie zachował należytej staranności, chociaż powinien i zarazem mógł to zrobić w danych okolicznościach. Wspomniany w powyższych rozważaniach wzorzec należytej staranności

22 J. Jastrzębski, O umowach o świadczenie niemożliwe versus umowa gwarancyjna (problem wyktadni postanowień umownych), w: Księga pamiątkowa 60-lecia Sądu Arbitrażowego przy Krajowej Izbie Gospodarczej w Warszawie, red. J. Okolski, A. Całus, M. Pazdan, S. Sołtysiński, T. Wardyński, S. Wołodyka, Warszawa 2010, s. 801.

${ }^{23}$ M. Gutowski, op.cit., s. 194. 
tworzy się na podstawie obiektywnych kryteriów zgodnie $z$ art. 355 $\S 1$ k.c.

W literaturze panuje dominujący pogląd, że hipoteza normy tegoż przepisu obejmuje zachowania wpisujące się w reżim odpowiedzialności zarówno kontraktowej, jak i deliktowej, o czym świadczy umiejscowienie przepisu w obrębie księgi III k.c. ${ }^{24}$ Dłużnik obowiązany jest do staranności ogólnie wymaganej w stosunkach danego rodzaju. W doktrynie podkreśla się, że normatywny kształt art. 355 k.c. jest przejawem obiektywizacji pojęcia winy. Ustawa nie nakazuje tu bowiem wnikać w psychikę dłużnika i badać, jaki był jego mentalny stosunek do czynu. Komentowany artykuł jest podstawą do ukształtowania obiektywnego wzorca postępowania, który dotyczy zarówno dłużnika w ogólności, jak i dłużnika występującego $\mathrm{w}$ poszczególnych stosunkach obligacyjnych. Ustalenie, czy konkretny dłużnik działał starannie, czy jednak dopuścił się niedbalstwa, następuje przez porównanie zachowania tego dłużnika $z$ odpowiednim wzorcem. Ocena staranności będzie oceną abstrakcyjną (in abstracto), ale dokonaną w odniesieniu do konkretnych okoliczności, w jakich działał sprawca ${ }^{25}$. Należy jednak dodać, że mogą pojawić się sytuacje, w których o zasadności zarzutu braku wymaganej staranności w dopełnieniu obowiązków decyduje nie tylko sama niezgodność postępowania $\mathrm{z}$ zachowaniem modelowym, lecz także możliwość i powinność przewidywania jego następstw warunkowana doświadczeniem życiowym ${ }^{26}$.

Zasadnym wydaje się podzielenie zapatrywań Biruty Lewaszkiewicz-Petrykowskiej, że w ujęciu k.c. należy postawić znak równości pomiędzy pojęciem należytej staranności, a pojęciem staranności ogólnie wymaganej w stosunkach danego rodzaju. Przymiotnik „należyty” określa bowiem sposób postępowania jednostki jako wła-

${ }^{24}$ S. Grobel, Pojęcie rażącego niedbalstwa $w$ kodeksie cywilnym, „Nowe Prawo” 1978, nr 5, s. 704 i n., a także A. Szpunar, Czyny niedozwolone $w$ kodeksie cywilnym, „Studia Cywilistyczne” 1970, t. XV, s. 54 i n.

${ }^{25}$ G. Bieniek, w: G. Bieniek, H. Ciepła, S. Dmowski, J. Gudowski, K. Kołakowski, M. Sychowicz, T. Wiśniewski, C. Żuławska, Komentarz do Kodeksu cywilnego, Księga III, Zobowiązania, tom. I, Warszawa 2011, s. 219.

${ }^{26}$ Zob. wyrok SO w Kaliszu z 18 listopada 2013 r., II Ca 442/13, Lex nr 1716920. 
ściwy do danych warunków czy też taki jak należy. Chodzi zatem o wymóg staranności ogólnie wymaganej, a nie ogólnie dokładnej. „Staranność ogólnie wymagana to taka, jakiej mamy prawo oczekiwać, jakiej powinniśmy się spodziewać, na jaką wreszcie mamy prawo liczyć. Problem powinien być rozwiązany na płaszczyźnie powinności, a nie faktu. Nieprawidłowa praktyka lub powszechnie występujące niedokładne wypełnianie powinności zawodowych, w szczególności np. respektowanie sprzecznego $z$ obowiązkiem ostrożności zwyczaju, nigdy nie mogą ekskulpować sprawcy"27.

Artykuł 355 § 2 stanowi, że należytą staranność dłużnika w zakresie prowadzonej przez niego działalności gospodarczej określa się przy uwzględnieniu zawodowego charakteru tej działalności. Jest to dodatkowe kryterium oceny należytej staranności w odniesieniu do osób prowadzących działalność gospodarczą (w ten sposób oznaczono wszystkich przedsiębiorców, których dotyczy art. $43^{1}$ k.c.). Zawodowy charakter działalności powoduje u kontrahentów uzasadnione oczekiwanie szczególnej sumienności i fachowej wiedzy przy wywiązywaniu się z obowiązków. Ustalając wzorzec należytej staranności, należy zatem uwzględniać nie indywidualne cechy dłużnika, lecz oczekiwania społeczne wobec osób, które znalazły się w sytuacji określonego typu. Będą to więc konkretne wzorce przystosowane do sytuacji typowych, ale różnych np. ze względu na wykonywaną profesję ${ }^{28}$.

Należyta staranność w zakresie prowadzonej działalności gospodarczej nie oznacza jednak staranności wyjątkowej, lecz dostosowanej do działającej osoby, przedmiotu, jakiego działanie dotyczy, oraz okoliczności, w jakich działanie to następuje ${ }^{29}$. Branie pod uwagę zawodowego charakteru działalności pociąga za sobą zwięk-

${ }^{27}$ B. Lewaszkiewicz-Petrykowska, Wina lekarza i zakładu opieki zdrowotnej jako przesłanka odpowiedzialności cywilnej za szkody wyrzadzone przy leczeniu, „Prawo i Medycyna” 1999, nr 1, s. 121.

${ }^{28}$ J. Ciszewski, w: Kodeks cywilny. Komentarz, wyd. II, red. J. Ciszewski, Warszawa 2014.

${ }^{29}$ Zob. wyrok SN z 25 września 2002 r., I CKN 971/2000, niepubl. Por. także wyrok SN z 5 lutego 2002 r., II CKN 894/99, niepubl. oraz wyrok SN z 11 stycznia 2002 r., IV CKN 544/00, niepubl. 
szenie zakresu odpowiedzialności względem dłużnika ${ }^{30}$. Jak słusznie zostało uwypuklone przez Sąd Najwyższy, art. 355 § 2 k.c. nie wymaga wyższej staranności wobec przeciętnej (ogólnej) wymaganej w obrocie powszechnym, lecz staranności zawodowej, a więc innej niż powszechna, mającej wzorce konstruowane od razu z uwzględnieniem profesjonalności podmiotów, której dotyczy. Należyta staranność osoby zawodowo wykonującej zobowiązanie (poza wypadkami, w których strony ukształtowały swoje zobowiązania w sposób odmienny) jest rozumiana jako przeciętnie wymagana, a więc zachowująca ustaloną wzorcem średnią na wystarczającym poziomie, na tyle dobrym, aby prawidłowo wykonać czynności zawodowe. Nie jest to więc staranność najwyższa, dlatego co do zasady adwokat i radca prawny nie muszą legitymować się wiedzą (umiejętnościami) ponad średni poziom istniejący wśród jego profesji, „nie ma zatem wykazywać dla zachowania należytej staranności, że ma wiedzę i umiejętności wybitne, ale jest nieodzowne, aby wykazał posiadanie kompetencji zawodowych w sprawach, których prowadzenia się podejmuje. Profesjonalny pełnomocnik powinien podejmować się sporządzania opinii i reprezentowania strony w zakresie takich dziedzin prawa, które dobrze zna od strony normatywnej, teoretycznej i zastosowania w praktyce, zwłaszcza poprzez orzecznictwo, a także uwzględniając wystarczające doświadczenie zawodowe i życiowe. Wszystkie te elementy składają się na wzorzec staranności zawodowej adwokata (podobnie radcy prawnego) w rozumieniu art. $355 \S 2$ k.c." ${ }^{31}$. Sąd, badając okoliczności danej sprawy, posiada wyłączną kompetencję do oceny, czy spełniona została przesłanka obiektywna i subiektywna winy adwokata czy radcy prawnego. Wzorzec jest budowany według obiektywnych kryteriów takiego poziomu fachowości, poniżej którego postępowanie danego podmiotu należy ocenić negatywnie. O zawinieniu może zdecydować nie tylko zarzucenie braku wystarczającej wiedzy i umiejętności praktycznych, odpowiadających aprobowanemu

${ }^{30}$ M. Safjan, w: Komentarz do art. 1-449 (11) KC, red. K. Pietrzykowski, Warszawa 2008, s. 936.

${ }^{31}$ Zob. wyrok SN z 15 marca 2012 r., I CSK 330/11, „Orzecznictwo Sądu Najwyższego. Izba Cywilna” 2012, nr 9, poz. 109. 
wzorcowi należytej staranności, ale także niezręczność i nieuwaga przeprowadzanych spraw, jeżeli - oceniając obiektywnie - nie powinny one wystąpić w konkretnych okolicznościach. Sąd Najwyższy ujął tę problematykę w sposób bardzo syntetyczny, stwierdzając, że „nie chodzi zatem o staranność wyższą od przeciętnej wymaganej wobec" zastępcy procesowego, ,jak to formułuje się w niektórych wypowiedziach, lecz o wysoki poziom przeciętnej staranności każdego” zastępcy procesowego ,jako staranności zawodowej (art. 355 $\S 2$ ) i według tej przeciętnej ocenianie konkretnego zachowania" ${ }^{32}$. Ustawodawca w szczególny sposób postrzega należytą staranność $\mathrm{w}$ odniesieniu do profesjonalnych uczestników obrotu. Miara staranności dla tej kategorii podmiotów stosunków zobowiązaniowych jest podwyższona i oceniana przez pryzmat zawodowego charakteru działalności dłużnika na podstawie art. $355 \S 2^{33}$. Adwokat i radca prawny powinni zachować należytą staranność zarówno wtedy, gdy chodzi o czynność odpłatną, jak i wówczas, gdy wykonuje czynność nieodpłatną ${ }^{34}$.

Czerwińska podkreśla brak jednoznacznych definicji ustawowych określających sposób reprezentacji klientów i zakres ich obowiązków. Poza wzięciem pod uwagę regulacji ustawowych i zawodowych w tym przedmiocie niezbędne jest odwołanie się do bogatego orzecznictwa doprecyzowującego obowiązki profesjonalnych pełnomocników wobec swoich klientów oraz rozwijającego zasady odpowiedzialności, za których przekroczenie mogą zostać oni pociągnięci do odpowiedzialności odszkodowawczej ${ }^{35}$. Umowa o świadczenie jest umową co do starannego działania, nie można więc w niej zobowiązać do doprowadzenia do konkretnego rezultatu. Niekorzystne z punktu widzenia interesów mocodawcy zakończenie sprawy nie rodzi odpowiedzialności odszkodowawczej, jeżeli pełnomocnik podjął

32 Zob. wyrok SN z 10 lutego 2010 r., V CSK 287/09, Lex nr 786561, a także wyrok SN z 17 sierpnia 1993 r., II CRN 77/93, „Orzecznictwo Sądu Najwyższego Izby Cywilnej, Pracy i Ubezpieczeń Społecznych” 1994, nr 3, poz. 69.

${ }_{33}$ Z. Gawlik, Komentarz do art. 472, pkt 10, w: Kodeks cywilny, Tom 3, red. A. Kidyba, Warszawa 2010.

${ }^{34}$ Zob. wyrok SN z 11 grudnia 1986 r., IV CR 424/86, Lex nr 8799.

${ }^{35}$ H. Czerwińska, op.cit., s. 45 i n. 
wszystkie przewidziane prawem czynności w celu uzyskania pozytywnego efektu w postaci wyroku na korzyść klienta.

Adwokat i radca prawny odpowiadają za szkody wyrządzone mocodawcy wskutek własnych zaniedbań i błędów prowadzących do przegrania sprawy sądowej, której wynik byłby korzystny dla strony, gdyby pełnomocnik zachował należytą staranność, ocenioną przy uwzględnieniu profesjonalnego charakteru jego działalności ${ }^{36}$. Nie ma także znaczenia, $z$ iloma osobami współpracuje pełnomocnik, prowadząc daną sprawę, gdyż jego odpowiedzialność obejmuje działania wszystkich osób, z których pomocy korzysta wykonując swój zawód ${ }^{37}$. Pełnomocnik wykonujący zawód samodzielnie w ramach kancelarii odpowiada za szkodę spowodowaną wadliwą pomocą prawną w sposób nieograniczony, osobiście i wprost. Jednakże profesjonalni pełnomocnicy mają obowiązek zawarcia stosownych umów ubezpieczenia OC, które to ułatwiają dochodzenie przez klientów odpowiednich roszczeń, gdyż mogą zwrócić się z nimi bezpośrednio do ubezpieczyciela.

\section{Należyta staranność adwokatów w prawie amerykańskim}

Na gruncie amerykańskiego common law profesjonaliści wykonujący określone zawody mogą zostać pociągnięci do odpowiedzialności przez swoich klientów na podstawie trzech podstaw: naruszenia postanowień kontraktu (breach of contract), deliktu niedbalstwa (negligence) oraz oszustwa (fraud). Pojęcie niedbalstwa związane jest $z$ prawem deliktów (tort law), będącym odrębnym aspektem prawa normującego naruszenie zobowiązań umownych ${ }^{38}$. Delikty niedbalstwa w wielu wypadkach są skutkiem lekkomyślności oraz stanowią najczęściej występujący rodzaj deliktów w sprawach sądowych na terenie Stanów Zjednoczonych. Od profesjonalistów takich

${ }^{36}$ Zob. wyrok SN z 10 grudnia 2012 r., II CSK 219/12, Lex nr 1294221.

${ }_{37}$ Zob. wyrok NSA z 11 czerwca 2014 r., I FZ 149/14, Lex nr 1469523.

${ }^{38}$ R. Tokarczyk, Zarys zagadnień amerykańskiego prawa deliktów, „Palestra” 1997, nr 5-6, s. 156-165. 
zawodów jak m.in. lekarze, architekci, adwokaci czy księgowi opinia publiczna wymaga dostarczania fachowych usług, spełniających określone standardy akceptowalne w ramach danego zawodu ${ }^{39}$. Przy ich wykonywaniu szczególnie zwraca się uwagę na działania lege artis, a więc zgodne $\mathrm{z}$ określonymi, powszechnie obowiązującymi standardami. Oprócz samych obowiązków wynikających z zawartej umowy, przedstawicieli zawodów w szczególności obowiązują standardy postępowania (standards of conduct), kodeksy etyczne (athical codes), prawo stanowe oraz orzecznictwo sądowe. Dla zawodu adwokata w kontekście obowiązku staranności (duty of care) nacisk należy położyć na przepisy stanowe, wypracowane przez judykaturę linie orzecznicze oraz Model Rules of Professional Conduct ustanowione przez American Bar Association ${ }^{40}$.

Status profesjonalisty, jakim jest zastępca procesowy, wymaga od danej osoby posiadania wiedzy oraz umiejętności specjalistycznych, których nie ma zwyczajna osoba. Sąd bierze pod uwagę także doświadczenie oraz praktykę danej osoby ${ }^{41}$. W przypadku naruszenia przez adwokata należytej staranności względem klienta będziemy mieć do czynienia $z$ tzw. professional negligance lub tzw. legal malpractice. Pojęcie to definiowane jest jako niedbałość zawodowa czy też błąd w sztuce. Termin ten związany jest $z$ naruszeniem standardów przy świadczeniu usług wymagających określonego stopnia umiejętności oraz wiedzy powszechnie stosowanych w danych okolicznościach przez przeciętnego, rozważnego i godnego zaufania członka danej profesji, skutkującym wystąpieniem szeroko pojętej szkody po stronie odbiorcy usługi ${ }^{42}$. Zachowanie odbiegające od modelowego poziomu stworzonego na podstawie wyznaczonych

39 K.W. Clarkson, R. LeRoy Miller, G.A. Jentz, F.B. Cross, Business Law Text and Cases. Legal, ethical, global, and e-commerce environment, wyd. 11 , Chula Vista, California 2008, s. 1048 i n.

${ }^{40}$ Zob. American Bar Association, Model Rules of Professional Conduct www.americanbar.org/groups/professional_responsibility/publications/model_ rules_of_professional_conduct (dostęp: 20.07.2020 r.).

${ }^{41}$ K.W. Clarkson, R. LeRoy Miller, G.A. Jentz, F.B. Cross, op. cit.

42 Zob. Professional negligence, w: USLegal, www.definitions.uslegal.com/p/ /professional-negligence/ (dostęp: 20.07.2020 r.). 
standardów, niewykazujące zachowania staranności, jest traktowane jako delikt niedbalstwa.

Adwokaci zobowiązani są do kompetentnej i rzetelnej reprezentacji swoich mocodawców, co musi wiązać się ze znajomością zasad prawa, którego dotyczy dana sprawa, posiadaniem umiejętności wyszukiwania potrzebnych rozwiązań prawnych oraz badania i odkrywania potencjalnych faktów, które mogą wpłynąć na sytuację prawną klienta ${ }^{43}$. Odejście od omawianego profesjonalnego wzorca będzie powodować naruszenie staranności (negligence) i narażenie się amerykańskiemu reżimowi odpowiedzialności deliktowej. W orzecznictwie istnieje spór co do konkretnych elementów jakościowych, które mają być składowymi danego wzorca ${ }^{44}$. Steven Wisotsky zwrócił uwagę na występowanie w praktyce tzw. appellate malpractice, a więc sytuacji, w której adwokat nie dochowuje należytej staranności na etapie postępowania odwoławczego, co jest szczególnie dotkliwe dla klientów poprzez częsty brak możliwości powołania się przed sądem, w którym toczyło się postępowanie, na uchybienia dokonane swoich pełnomocników, a zatem możliwości powstania szkód o większych rozmiarach niż w przypadku innych sytuacji $^{45}$. Tego typu negatywne zjawisko cechuje się więc większym ciężarem gatunkowym. Powoduje, że konsekwencje niedołożenia należytej staranności są znacznie bardziej dotkliwe dla profesjonalnego pełnomocnika ze względu na rozmiar powstałej szkody.

Adwokat przy wykonywaniu swojego zawodu nigdy nie jest zobowiązany do zachowania nadzwyczajnej staranności, na co zwrócił uwagę Sąd Najwyższy stanu Michigan, przytaczając w swoim wyroku utartą przez lata linię orzeczniczą amerykańskich sądów ${ }^{46}$. Profesjonalny pełnomocnik nie jest także „ubezpieczycielem” możliwego do osiągnięcia rezultatu w podejmowanej przez niego sprawie, chyba że obydwie strony zawrzą specjalną umowę co do rezultatu,

\footnotetext{
${ }^{43}$ K.W. Clarkson, R. LeRoy Miller, G.A. Jentz, F.B. Cross, op. cit.

${ }^{4}$ J.W. Wade, The Attorney's Liability for Negligence, "Vanderbilt Law Review" 1959, Issue 3 - Symposium on Professional Negligence, s. 774 in fine i n.

45 S. Wisotsky, Appellate Malpractice, "The Journal of Appellate Practice and Process" 2002, vol. 4, issue 2.

${ }^{46}$ Zob. Simko v. Blake, 532 N.W.2d 842 (Mich. 1995).
} 
aby osiągnąć pożądany przez klienta cel i związać niejako adwokata z odpowiedzialnością za ostateczny efekt jego pracy. Tego rodzaju umowę należy także przewidzieć w sytuacji, w której pożądane jest, aby adwokat cechował się ponadprzeciętną wiedzą i umiejętnościami w konkretnej sprawie ${ }^{47}$. Adwokat nie może również ponieść odpowiedzialności za błąd co do zagadnienia prawnego, które może budzić wątpliwości nawet u obeznanych prawników ${ }^{48}$.

\section{Podsumowanie}

We współczesnym prawie cywilnym bezsporna jest zasada podnoszenia odpowiedzialności przez adwokatów i radców prawnych prowadzących indywidualną praktykę prawniczą za zachowania niezgodne ze wzorcem należytej staranności. Uwaga ta dotyczy zarówno polskiego, jak i amerykańskiego systemu prawnego.

Opierając się na obszernej literaturze przedmiotu oraz aktualnych poglądach judykatury, należy stwierdzić, że w Polsce pomimo występowania pojęcia niezachowania należytej staranności zarówno przy działaniu bądź zaniechaniu umyślnym, jak i nieumyślnym profesjonalnego pełnomocnika zagadnienie to ma największe znaczenie właśnie przy winie nieumyślnej. W Stanach Zjednoczonych pojęcie należytej staranności (due care) profesjonalnego pełnomocnika występuje przy delikcie niedbalstwa (negligence), a jej naruszenie (legal malpractice) warunkowane jest faktem uchylenia się od określonych standardów. Na gruncie polskiego porządku prawnego również tworzy się wzorzec prawidłowego zachowania, który ze względu na złożoność oraz specyfikę każdej sprawy musi być zobiektywizowany i zawierać istotne okoliczności sprawy. Odpowiedzialność oparta jest jednak na reżimie art. 471 k.c., a nie odpowiedzialności za czyn niedozwolony. W obu analizowanych systemach prawnych ciężar udowodnienia spoczywa na mocodawcy (powodzie), który chce uzyskać naprawienie szkody spowodowanej przez niedbalstwo

47 Zob. Bessman v. Weiss, 161 N.W.2d 599, 11 Mich. App. 528 (1968).

${ }^{48}$ Zob. Kirsch v. Duryea - 21 Cal. 3d 303, 146 Cal. Rptr. 218, 578 P.2d 935 (1978), a także Lally v. Kuster, 48 Cal. App. 355, 292 P. 78 (Cal. Ct. App. 1920). 
profesjonalnego pełnomocnika. Orzecznictwo polskich sądów oraz Trybunału Konstytucyjnego odgrywa niebagatelną rolę w porządkowaniu oraz rozwoju zasad odpowiedzialności na płaszczyźnie wskazanej problematyki. Kompetencja sądów do wnikliwego badania zaskarżonej działalności pełnomocników i jej retrospektywnej oceny jest niezbędna do przypisania tym podmiotom winy. Równoległe zjawisko ukształtowało się w Stanach Zjednoczonych, gdzie system common law kładzie jeszcze większy nacisk na znaczenie judykatury. Niejednokrotnie wyznaczenie precyzyjnej granicy pomiędzy zachowaniem a niezachowaniem należytej staranności, wymaganej w konkretnych okolicznościach, jest zadaniem trudnym. Stanowi ono dla składu orzekającego oraz innych aktorów postępowań sądowych wyzwanie, które w wielu wypadkach powoduje konflikty oraz wątpliwości. Dlatego niezbędne staje się dokładne zbadanie łączącego strony stosunku prawnego, uwzględnienie znaczących okoliczności sprawy oraz znajomość poglądów doktryny i orzecznictwa, które pomagają w rozwiązywaniu powstałych na płaszczyźnie prawa problemów.

\title{
STRESZCZENIE
}

\author{
Należyta staranność adwokata i radcy prawnego \\ wykonujących zawód w ramach indywidualnej \\ praktyki prawniczej (analiza porównawcza polskiego \\ i amerykańskiego systemu prawnego)
}

Autor dokonuje analizy pojęcia należytej staranności w polskim i amerykańskim prawie cywilnym $\mathrm{w}$ aspekcie indywidualnej praktyki zawodu profesjonalnego pełnomocnika. Prowadzone studium dotyczy dyskusji o odpowiedzialności w przedmiotowej sprawie oraz reżimu prawnego, który tworzą kluczowe przepisy polskiego kodeksu cywilnego, poglądy polskiej judykatury i orzeczenia sądów amerykańskich. W tym miejscu poświęcono uwagę problemowi definicji oraz rozgraniczenia semantycznego zakresu klauzuli należytej staranności, a także opinii doktryny i sądownictwa dotyczących związanych z nimi zagadnień praktycznych. Niniejszy artykuł obejmuje próby wskazania przez autora istotnych okoliczności, które powodują powstanie odpowiedzialności cywilnej za nienależyte wykonanie czynności przez profesjonalnego pełnomocnika. 
Słowa kluczowe: należyta staranność; odpowiedzialność; adwokat; radca prawny; zawód zaufania

\section{SUMMARY}

Due diligence in Polish civil law in the aspect of individual legal practice of the profession of attorney (comparative analysis of Polish and US legal systems)

The Author of the article conducts an analysis of the concept of due diligence in Polish and US civil law in the aspect of individual legal practice of the profession of attorney. The study concerns the discussion of the liability in the subject matter and the legal regime that is created by the key articles of Polish Civil Code, views of Polish judicial decisions and the US judicial decisions. Herein an attention has been devoted to the problem of the definition and demarcation of the semantic range of the due diligence clause, opinions of the doctrine and judicature and the practical issues. This paper includes the attempts of the author to indicate the relevant circumstances which give the rise to civil liability for legal malpractice.

Keywords: due diligence; legal malpractice; liability; attorney; profession of public trust

\section{BIBLIOGRAFIA}

American Bar Association, Model Rules of Professional Conduct www. americanbar.org/groups/professional_responsibility/publications/model_rules_of_professional_conduct (dostęp: 20.07.2020 r.).

Banaszak B., Konstytucja Rzeczpospolitej Polskiej. Komentarz, wyd. 2, Warszawa 2012.

Bieniek G., w: G. Bieniek, H. Ciepła, S. Dmowski, J. Gudowski J, K. Kołakowski, M. Sychowicz, T. Wiśniewski, C. Żuławska, Komentarz do Kodeksu cywilnego, Księga III, Zobowiązania, tom I, Warszawa 2011.

Ciszewski J., w: Kodeks cywilny. Komentarz, wyd. II, red. J. Ciszewski, Warszawa 2014.

Clarkson K.W., Miller LeRoy R., Jentz G.A., Cross F.B., "Business Law Text and Cases. Legal”, ethical, global, and e-commerce environments, wyd. 11, Chula Vista, California 2008. 
Czerwińska H., Odpowiedzialność cywilna adwokata na tle ubezpieczenia OC - uwagi $w$ świetle wybranych orzeczeń sadowych, „Wiadomości Ubezpieczeniowe" 2014, nr 1.

Dybowski T., w: System prawa prywatnego, tom III, red. T. Dybowski, Warszawa 2013.

Gawlik Z., w: Kodeks cywilny, Tom 3, red. A. Kidyba, Warszawa 2010.

Grobel S., Pojęcie rażącego niedbalstwa $w$ kodeksie cywilnym, „Nowe Prawo" 1978, nr 5.

Gutowski M., Umowa o zastępstwo procesowe, Warszawa 2009.

Jastrzębski J., O umowach o świadczenie niemożliwe versus umowa gwarancyjna (problem wykładni postanowień umownych), w: Księga pamiątkowa 60-lecia Sądu Arbitrażowego przy Krajowej Izbie Gospodarczej $w$ Warszawie, red. J. Okolski, A. Całus, M. Pazdan, S. Sołtysiński, T. Wardyński, S. Wołodyka, Warszawa 2010.

Lewaszkiewicz-Petrykowska B., Wina lekarza i zakładu opieki zdrowotnej jako przesłanka odpowiedzialności cywilnej za szkody wyrzadzone przy leczeniu, „Prawo i Medycyna” 1999, nr 1.

Professional negligence w: USLegal, www.definitions.uslegal.com/p/professional-negligence/ (dostęp: 20.07.2020 r.).

Radwański Z., Olejniczak A., Zobowiązania - część ogólna, wyd. 13, Warszawa 2018.

Safjan M., Komentarz do art. 1-449(10) w: Kodeks cywilny, tom. I, red. K. Pietrzykowski, Warszawa 2018.

Sarnecki P., Pojęcie zawodu zaufania publicznego (art. 17 ust. 1 Konstytucji) na przykładzie adwokatury, w: Konstytucja - wybory - parlament. Studia ofiarowane Zdzisławowi Jaroszowi, red. L. Garlicki, Warszawa 2000.

Szpunar A., Czyny niedozwolone $w$ kodeksie cywilny, „Studia Cywilistyczne" 1970, t. XV.

Tokarczyk R., Zarys zagadnień amerykańskiego prawa deliktów, „Palestra” 1997, nr 5-6.

Wade J.W., The Attorney's Liability for Negligence, "Vanderbilt Law Review" 1959, Issue 3 - Symposium on Professional Negligence.

Wisotsky S., Appellate Malpractice, „The Journal of Appelate Practice and Process" 2002, vol. 4, issue 2.

Wiśniewski T., w: Bieniek G., Ciepła H., Dmowski S., Gudowski J., Kołakowski K., Sychowicz M., Wiśniewski T., Żuławska C., Komentarz do Kodeksu cywilnego, Księga III, Zobowiązania, tom I, Warszawa 2011.

Wiśniewski T., w: Komentarz do Kodeksu cywilnego, Tom III, Zobowiązania, Część Ogólna, red. J. Gudowski, Warszawa 2013. 
